\title{
PARTIAL PREPARATORY STAGES OF SMERINTHUS OPHTHALMICUS, BD.
}

BY G. H. FRENCH, CARBONDALE, ILL.

After First Moult.-Length .45 inch. Cylindrical, head with an elevated point upwards, in a subpyramidal point, the top in two points and about a third higher than the body; when at rest the jaws under back part of head with the point obliquely forward. Eight transverse wrinkles to each joint; green studded with pale green points; a subdorsal pale line, as usual converging to caudal horn; on sides, oblique pale lines that nearly coincide with a series on the dorsum; the pale parts yellowish-green; caudal horn reddish tinted; head with a pale stripe on each side of face, the two coming together above. Previous to the next moult, smooth, the oblique lines showing very pale; the oblique stripe and caudal horn creamy-white; the anterior base of horn reddish. Duration of this period 5 days.

After Second Moult.-Length .90 inch. Colour green, a little dull and rather blue-tinted; each joint with 8 transverse folds that are studded with yellowish-green points that are but little lighter than the ground, a subdorsal line made of these points; a dorsal line and oblique stripe of the darker green without points, these lines defined by the points, on the sides below subdorsal line a similar stripe defined posteriorly by a row of these points more yellowish than the dorsal, the stripe that runs to the caudal horn creamy-white, as is also the caudal horn; the latter short hairy. Head pointed above as before and also the side of the face with a line of points more yellow than the last oblique stripe; thoracic feet redtinted. Duration of this period 5 days.

After Third Moult.-Length I.25 inches. Green, slightly bluish; head still pointed but not quite so prominent as in preceding stages, the stripe rounding at the top ; bluish-green, stripes yellow ; stripes on back and sides as before; caudal horn pale bluish purple, more blue at base, the stripe from this down the sides very pale lemon-yellow; prolegs concolorous; thoracic legs paler, red tipped, stigmata black ringed, centre creamy. Duration of this period 5 days.

After Fourth Moult.-Length 1.40 inches. Bright green of a yellowish tint; head blue-green; granulations more white; side stripes yellowish-green, the one that extends to the caudal horn creamy, with a 
slight greenish tint; caudal horn purple-blue, except the sides which are a continuation of the lateral stripe; jaws black, clypeus and anterior feet pale red; head blunt, stripe yellow; stripes on anal appendages yellow. Duration of this period 6 days.

Chrysalis.-Length r.35 inches; to the back of wing cases, .64 inch ; and this extends to posterior part of joint 5 ; depth through joint $5, .42$ inch; through $4, .40$ inch ; through $3, .39$ inch; through $2, .37$ inch; end of tongue case, .55 inch from the anterior end. Cylindrical, tapering gradually back from joint 5 , cremaster triangular tuberculate, especially on the dorsal part and on sides at base, round dorsally and flattened ventrally, no hooks but slightly forked terminally; head rounded. Colour chestnut-brown, nearly uniform ; wing, tongue and leg cases a little darker than the rest; the abdomen slightly punctured. Duration of this period I 5 to 17 days.

A comparison of the pupæ of this species with Geminatus shows the following differences:- The cremaster on Geminatus is triangular, more slender, less roughly tuberculate dorsally and laterally; this in Ophthalmicus having a distinct tubercle each side at the base that is lacking in Geminatus. The cremaster in Geminatus is nearly conical by reason of its being only slightly flattened ventrally, while in Ophthalmicus it is distinctly flattened ventrally, and dorsally is contracted at the base. A chrysalis of Geminatus measures as follows: Length $1 . J 5$ inches; depth through joint $5, .40$ inch; joint $4, .38$ inch; joint $3, .37$ inch; length to end of wing cases, .60 inch; to end of tongue case, .48 inch. A comparison of these figures with the measurements of Ophthalmicus shows a different proportion between the two pupæ. The pupa skin is about twice as stiff in Geminatus as it is in Ophthalmicus. Besides this, the larva of Ophthalmicus differs from that of Geminatus in being less cylendrical, the third and fourth joints being enlarged, thereby making it resemble the larvæ of Everyx Myron.

The food plant is the same as that of Geminatus.

The larva from which the above descriptions were made were received from the Hon. C. F. McGlashan, of Truckee, California. They were sent

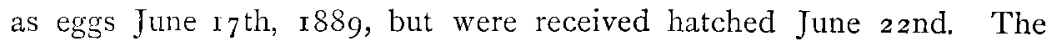
imagines were produced August 2nd and 3 rd of the same year, making a total period from egg to imago, of the summer brood, of 47 days. The time of hatching shows that there are two broods in a season. 